\title{
Impact of School Leadership on Students Personality Development
}

\author{
* Muhammad Asif Kamal, PhD Scholar \\ ** Dr. Zairab Mahmood, Assistant Professor \\ *** Dr. Muhammad Ishaq, Assistant Professor \& Director QEC
}

\begin{abstract}
The study was to investigate the impact of school leadership on student's personality development. The objectives of the study were to investigate the characteristics of competent school leadership and to find out the factors which develop students' personality. The nature of the study was descriptive. There were forty principals (one post was vacant) and two hundred ninety-one senior teachers in forty-one secondary schools in district Mirpur Azad Kashmir. Thirteen principals and a hundred teachers were selected randomly from the target population. A questionnaire of twenty items was developed from the relevant literature. The questionnaire was examined by two experts while the coefficient of reliability was 0.93. Data were collected through personal visits. It was concluded that the school leadership develops the students' personalities. The study provided suggestions in the recruitment and promotion process of school principals that preference should be given to those candidates who have an ideal track record for promotion as the school principal.
\end{abstract}

Keywords: School, Personality, Leadership, Skills, Development

Introduction

In the $21^{\text {st }}$ century, for the weightier performance of the school and student outcomes, the school leadership is the greatest part of the school. It is possible only through the constructive and singleminded leadership and its team (Bush, 2008). Leadership and management in education are concerned with the operation of schools and related educational organizations. The function of management is to siphon out well-set policies formulated by the leadership (Bolam, 1999).

Leadership and management in educational fields is the study and practice concerned with the operation of schools and other educational organizations. Supre (2002, p.102) stated, Management is a set of activities focused towards well-organized and operational deployment of organizational resources to unzip legalistic goal.

Management is concerned with the internal institutional self-mastery of directed policies. Bush (2008) quoted Glatter (1979, p.16), management studies are wondering with 'the internal relationships with their environment, that is, the communities in which they are set, and with the governing persons to which they are formally responsible'.

The quality of leadership is vital for school effectiveness and student outcomes. Huber (2004a, pp.1-2) claimed that schools categorized as successful possess a competent and comprehensive school leadership and failure often toadies with poor school leadership. Leithwood, (2006, p.5) stated that there is virtually its pupil victory trajectory in the sparsity of talented leadership.

Moral leadership has to be on the values, beliefs, ethics, and values of leaders themselves. Sergiovanni (1984, p.10) said, "Outstanding schools have inside well-balanced of values and beliefs that take on sacred or cultural characteristics". He added that 'administration' is a moral craft.

Leadership without purpose is a contradiction. Effective leaders have a keen sense of what they hope to realize and are worldly-wise to communicate a way to others with whom they work. This strength of leader beliefs and the worthiness to stir the devotion and transferal of others to these beliefs knowing what is important and personally sharing and convincingly wanted by others.

* Mohi-ud-Din Islamic University, AJK

** Mohi-ud-Din Islamic University, Nerian Sharif AJK

*** Mohi-ud-Din Islamic University, Nerian Sharif AJK

Email: Muhammadishaq@miu.edu.pk 
The importance of effective school leadership for the successful function has been recognized. For possible desired school results for learners and stakeholders, the quality of school leaders and leadership is critical.

School, being a part of society, is responsible to transmit the social values, culture, beliefs, ethics, and religious thoughts to their learners. It is only possible when learners see the model personalities practicing societal values in schools.

The child is a clean slate but is an important member of the society. He learns and accepts what the school environment prepares him. When school leadership demonstrates the social and religious thoughts and provides the environment in a good sense, the learner adopts these values and thoughts. So the school leadership is the major factor in developing students' personalities. In this study, it was attempted to study the impact of school leadership on students' personality.

\section{Review of Literature}

Leadership is the characteristic of a person to create an impact to motivate others toward having advantageous objectives and targets. Individuals' maturation has a positive tendency can explore or expect reactions of others and strongly impress or motivate others toward the predefined objectives. Constructive influence is an impression of a man who has a positive self-regard, lofty moral values, and fearlessness were overcome and ultimate on is not present (Goleman, 1998). The non-resisted impacts make an atmosphere that leaves a feeling of accomplishment in the individuals who take advantage of it.

School leadership and the other members directly involved for the betterment and the uplift of the student character and his innocent personally. The students' academic outstanding and concrete achievement, school principal plays a vital and dynamic role (Leith, 2004) to arrange the superior management of the school so that it may assist the entire atmosphere to develop the personality of the student and also helps to strengthen the coordination of the teaching staff (Wekessa, 1997). School principal ensures enabling environment for teaching-learning practices for the student academic achievement (Liebowitz, 2019).

The headmaster, headmistress, or school principal is a teacher who has loftiest responsibilities for management in school. Principal due to his highest rank in school, has a tremendous and leading part in educational institutions. He plays a key role in the delivery of golden instruction to the students as well as their parents and relatives. His responsibilities including ensuring educational policies are in place that motivates the student for his/her effective learning process. He serves as a: facilitator, guide, helper for quality instructional practices, and reaction and he serves as the dynamic educational leader of the school. A principal has a working knowledge of effective instructional policies and can at once perceive or understand necessities and the needs of his teachers and students.

Generally, it was being said and now it is said that the school principal should be well qualified and have ripe experience to run or handle the affairs of his institution under any circumstances. It is admitted fact that administration or leadership is parallel which needs peculiar training. Good administrators are well-informed and communicate crystal steps of individual and educational values which shows their moral purposes for the school (Wasserberg, 2000).

School runs under the supervision of a team, a group of school administrators, teachers, and other supporting staff under who important governing decisions are made. These team members lead and coordinate school improvement activities. However, the composition of team members varies widely from school to school because some schools may include also student, parent, and external responsible representatives of society.

Traditionally, the school leadership team might include 'Head of Departments', 'Internal Controller of Examination (ICE)', 'Head of Internal Enhancement Committee (IAC)', 'Chairman of Discipline Committee' etc.

The role of the leadership team may vary from school to school or district to district. However, its role is:

$>\quad$ To initiate developing, coordinating, and leading school improvement activities.

$>\quad$ Responsible to analyze students' performance data and propose specific strategies to address the instructional area in need of improvement.

To create an environment in encouraging facilitating and supporting greater collaboration among teachers in the school.

To see and improve professional development opportunities for teachers and staff members. 
To select, revise and update the curriculum and learning technologies.

$>\quad$ To support the head of school in resolving issues related to faculty relationships, school's professional, social, and academic culture.

Personality is the reflection of all psychology but the highest objective of the education and its environment is to refine and polish learner's personalities. Personality is the fruit and result of those activities that transmit and provide reliable information over a long period (Jerom, 1997).

English (2006, p.743) said, "The psychological structure of personality affects education in a variety of significant ways, including student achievement and performance, faculty performance, and leadership styles and capabilities". Rashid, M.(1997, p.45) said, "Personality is a dynamic organization with the individual of those psycho-physical systems that decide his distinguishing adaptation to his environment. The word dynamic means that personality is growing taking sophisticated uplift and changing and not something fixed or stagnant in this regard the inherited environments and slithering factors play an outstanding role in the proper construction of a student personality.

The word personality has been derived from the Latin words "Per" and Sonare", the term personal which means to 'sound through'.

Rashid (1997) cited that huge changes come into being over a few years in personality tendency and behavior and social organization because of the changing atmospheres and environment... What kind of school and teachers a child has left affect his emotional, social, and sagacious growth extend directly or indirectly. Social activities and environment interaction effect on child personality from the beginning and onwards (Person, 2014).

Khan $\mathrm{N}$ et al (2018) stated that the leaders may be followed in those places where their performance and personal leadership skill encourages youth for the better path to progress and development. They should be the source of motivation for the students and learners to make their personality attractive and fruitful in the future.

School environment is the major factor, affects the students' behavior and attitudes which are the part of their personality. It is the responsibility of school leadership to create the best possible environment in school where the students have to spend six to eight hours a day.

\section{Characteristics of Personality}

Rahman, (2014, pp: 54-55) stated the following characteristics of personality.

1. Personality is a set and code of psychological qualities of the individual.

2. It produces different ways and means of settlement and adjustment of people in a cluster or group.

3. Personality differs from person to person. No two individuals have the same personality.

4. It is situational contact-oriented. People's personality depends on the situational environment.

5. The personality of an individual cannot be stupid and stubborn and can easily be changed by the assistance of changing circumstances.

6. It creates an influence objective target attitude of individuals.

7. It is a measurable aspect and it can be indirectly achieved.

8. Personality puts a tremendous influence on the performance of individuals group and their organization.

Human resources are important factors in the field of educational activities. If the principal and the teachers are motivated enthusiastic, energetic, competent, and determined they can easily improve the standard and the quality of education and also can develop the reputation of the institution and its individuals. Human resources should be dedicated and have a desire to uplift the academics. Khan, quoted Marnazo. (2003) described that the principal must be the man of principles and he should have to put very thrilling influence upon the teaching staff. He must have the quality of head and heart. His behavior should be polite and submissive towards his teaching staff. This influence of principals has a positive impact on the school environment. Lezotte and Levine (1990), Corcoran, and Wilson (1989) stressed that the school leadership must be competent and determined in the field of teaching. They must impart a very healthy influence upon the dexterity and skills of the students. They must be strong and positive in the way of pedagogy and their teaching methodology should be according to the modern trend and tendency. They must focus on the mental and physical development of the students. They must deliver an effective atmosphere for the students. The 
principal and teachers must produce such an atmosphere that could be supported and positive for the students. In this way, they can make the institution a heaven on earth for the little students.

\section{Factors Affecting Personality Development}

Personality influences people who are about the traits, attitudes, and aptitudes of a person. It comprises many elements that work in functions as a whole in an organized manner. There are two main factors affecting personality development:

$>\quad$ Individual Factors

$>\quad$ Social/Environmental Factors

\section{Individual Factors}

i. $\quad$ Heredity $\rightarrow$ genetic transfer from parents to children

ii. Physique $\rightarrow$ biological makeup i.e. tall and thin, short and stout, muscular and well proportioned.

iii. Biological Factors $\rightarrow$ the endocrine glands like thyroid, parathyroid pituitary glands, adrenal glands, gonads, etc.

iv. Nervous System

v. Intelligence

\section{Social / Environmental Factors}

i. Family ii. School iii. Maturation iv. Experience

v. Success and Failures vi. Cultural

This paper was to study the impact of school leadership on students' personality development. So, the study was delimited to present the impact of social/environmental factors affecting personality development i.e. how school leadership creates a school environment which helps to develop students' personality in good manners.

\section{Time Spent by Students in School}

At least four hours per day, for students from pre-schooling to primary level, have to spend in school while students of elementary level spend six hours in school. Similarly, six hours and forty minutes (including forty minutes per day for laboratory work) are spent by the students of Secondary level students in school. There are 240 working days in one academic year for schools.

Teaching/learning environment comprises the simultaneous mutual exchange of ideas and interaction between teachers and learners, where learners have to organize themselves for work, to do the assigned task, and to make decisions that reveal something about study habits (Sheebha,2016).

A pupil's age up to fifteen to sixteen years, is very critical and important in developing his personality. He adopts what he sees or faces in school. School is a model of society where students spend their most of time.

\section{Method}

Research methodology is a systematic organized and logical way of collecting information from the participants to understand a phenomenon and to generalize the facts and results from a large population (Cohen, Manion, \& Morrison, 2000). This study was descriptive; the data were collected through questionnaires.

\section{Population}

The study was carried out in district Mirpur, Azad Jammu, and Kashmir. The population of the study was 40 principals and 291 senior teachers from 41 Govt. Boys High Schools (one principal of a school had died and the post was vacant).

\section{Sampling Technique and Sample Size}

A sample is a subpart of the population. Different sampling techniques may be used for selecting a sample at each stage according to the nature of the population. In the current study, 13 principals and 100 teachers were selected randomly. Thus, the total sample was comprised of 113 male teachers.

\section{Research Instrument}

A questionnaire was developed on a five-point Likert scale to collect data from the respondents. The questionnaire consisted of twenty items related to the practicing factors by the school leadership to see the impact on students' personality development.

\section{Validity of the Instrument}

To assess the level of accuracy of the measuring instrument and the extent of constructs that it claims to measure the content and construct validity of the questionnaire was studied by the two experts at 
the Mohiuddin Islamic University Narrian Shareef Sudnoti and Mian Muhammad Bakhsh Library Mirpur.

\section{Reliability of the Instrument}

The reliability of the questionnaire was assessed based on data obtained by pilot-testing through the Spearman-Brown split-half reliability formula. The reliability coefficient of the questionnaire was 0.93.

\section{Data Collection}

Data were collected through personal visits. So, a hundred percent of responses were received due to a follow-up study. Data was organized, tabulated, and analyzed through statistical tool, percentage.

\section{Data Analysis}

$\mathrm{A}=$ Strongly Agree $\quad \mathrm{A}=$ Agree $\quad \mathrm{N}=$ Neutral $\quad \mathrm{D}=$ Disagree $\quad \mathrm{SD}=$ Strongly Disagree

$\mathrm{F}=$ Frequency

1. MORAL VALUES

\begin{tabular}{llllllll}
\hline S. No. & Item & $\begin{array}{l}\text { SA } \\
\%\end{array}$ & $\begin{array}{l}\text { A } \\
\%\end{array}$ & $\begin{array}{l}\text { N } \\
\%\end{array}$ & $\begin{array}{l}\text { D } \\
\%\end{array}$ & $\begin{array}{l}\text { SD } \\
\%\end{array}$ & Mean \\
\hline 1. & Social Values & 56.64 & 34.52 & 4.42 & & 4.42 & 4.38 \\
2 & Religious Values & 51.33 & 40.71 & 3.54 & & 4.42 & 4.33 \\
3 & Behavioral Values & 27.43 & 64.61 & 7.69 & & & 4.19 \\
4 & Beliefs and Ethics & 46.02 & 50.44 & 3.54 & & & 4.30 \\
5 & Mutual Interaction & 47.79 & 45.13 & 7.08 & & & 4.41 \\
& Mean of the Means & & & & & & 4.32
\end{tabular}

Table 1 depicted the data about Moral values. It is evident from the table that in social values, $91.16 \%$ of participants agreed the statement, "The school leadership develops social values in students' personality." $4.42 \%$ of participants were neutral while $4.42 \%$ of participants were against the statement. So, it was proved the statement. Mean score 4.38 is significant to prove that the participants have the same opinion about the statement.

$92.04 \%$ of participants agreed the statement, "Religious thoughts of school leadership affect students' thoughts." $3.54 \%$ of participants were neutral while $4.42 \%$ of participants were against the statement. So, it was proved the statement. Mean score 4.33 is significant to prove that the participants have the same opinion about the statement.

92.04\% of participants agreed the statement, "The students are representatives of their school leadership school through their behavior and actions." $7.69 \%$ of participants were neutral while no one was against the statement. So, it was proved the statement. Mean score 4.19 is significant to prove that the participants have the same opinion about the statement.

$96.46 \%$ of participants agreed on the statement, "The school leadership develops beliefs and ethics in students' personality." $3.56 \%$ of participants were neutral while no one participant was against the statement. So, it was proved the statement. Mean score 4.30 is significant to prove that the participants have the same opinion about the statement.

93.92\% of participants agreed on the statement, "Mutual exchange of ideas and interaction between school leadership and students generates ability of discussion skills in students." $7.08 \%$ of participants were neutral while no one participant was against the statement. So, it was proved the statement. Mean score 4.41 is significant to prove that the participants have the same opinion about the statement.

Mean of the mean scores is 4.32 which mean that the data are statistically significant i.e. the school leadership develops moral values in students' personality.

2. EMOTIONAL VALUES

\begin{tabular}{llllllll}
\hline S. No. & \multicolumn{1}{c}{ Item } & $\begin{array}{c}\text { SA } \\
\%\end{array}$ & $\begin{array}{l}\mathrm{A} \\
\%\end{array}$ & $\begin{array}{l}\mathrm{N} \\
\%\end{array}$ & $\begin{array}{l}\mathrm{D} \\
\%\end{array}$ & $\begin{array}{l}\text { SD } \\
\%\end{array}$ & Mean \\
\hline 1. & Confidence & 44.25 & 46.02 & 8.83 & 0.9 & & 4.30 \\
2 & Patience & 35.40 & 57.52 & 3.54 & & 3.54 & 4.21 \\
3 & Peace & 39.82 & 60.18 & & & & 4.40 \\
4 & Attitude & 60.17 & 31.87 & 7.96 & & & 4.52 \\
& Mean of the Means & & & & & & 4.40
\end{tabular}

Table 2 reflects the data about Emotional values. It is evident from the table that in emotional values, $90.47 \%$ of participants agreed the statement, "Active participation of students in resolving 
school issues develops confidence in them." $8.83 \%$ of participants were neutral while $0.90 \%$ of participants were against the statement. So, it was proved the statement. Mean score 4.30 is significant to prove that the participants have the same opinion about the statement.

$92.92 \%$ of participants were in favour of the statement, "Patience is a prominent feature in the personality of the principal". $3.54 \%$ of participants were neutral while $3.54 \%$ of participants were against the statement. So, it was proved the statement. Mean score 4.21 is significant to prove that the participants have the same opinion about the statement.

$100 \%$ of participants agreed the statement, "Only a peaceful school leadership of an institution can generate enabling environment". No one was neutral and against the statement. So, it was proved the statement. Mean score 4.40 is significant to prove that the participants have the same opinion about the statement.

92.04\% of participants agreed the statement, "The attitudes and behavior of school leadership affect the students' personality". $7.96 \%$ of participants were neutral while no one participant was against the statement. So, it was proved the statement. Mean score 4.52 is significant to prove that the participants have the same opinion about the statement.

The mean of the mean scores is 4.40 which mean that the data are statistically significant i.e. the school leadership develops emotional values in students' personality.

3. ACADEMIC DEVELOPMENT

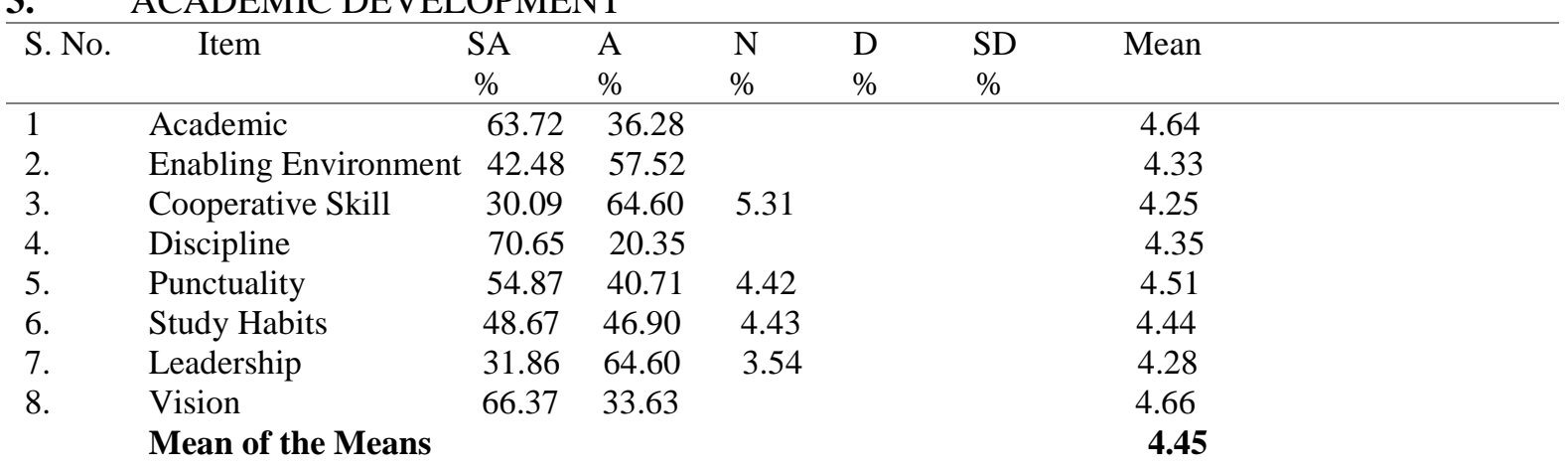

Table 3 reveals the data about 'Academic development'. It is evident from the table that:

$100 \%$ of participants agreed about the statement, "The school leadership plays a central role in student academic achievement". Neither participant was neutral nor was against the statement. Mean score 4.64 is significant to prove that the participants have the same opinion about the statement.

$100 \%$ participants in favour of the statement, "The school leadership is responsible to create enabling environment is a school". Neither participant was neutral nor was against the statement. Mean score 4.33 is significant to prove that the participants have the same opinion about the statement.

94.69\% of participants were in favour of the statement, "Collaborative approach of school leadership develops cooperative skills I students". 5.31\% of participants were neutral while no one was against the statement. Mean score 4.25 is significant to prove that the participants have the same opinion about the statement.

$100 \%$ of participants were in favour of the statement, "Well-disciplined school leadership develops discipline in students". Neither participant was neutral nor was against the statement. Mean score 4.40 is significant to prove that the participants have the same opinion about the statement.

$95.58 \%$ of participants were in favour of the statement, "Punctuality of school leadership develops responsible citizenship character in students". 5.31\% of participants were neutral no one was against the statement. Mean score 4.64 is significant to prove that the participants have the same opinion about the statement.

$95.57 \%$ of participants were in favour of the statement, "The students' participation in activities in school which reflects their study habits and develop their personality". $4.43 \%$ of participants were neutral no one was against the statement. Mean score 4.44 is significant to prove that the participants have the same opinion about the statement.

$96.46 \%$ of participants were in favour of the statement, "A dynamic school leadership develops energetic generation which leads the nation in future". $3.54 \%$ of participants were neutral no 
one was against the statement. Mean score 4.28 is significant to prove that the participants have the same opinion about the statement.

$100 \%$ of participants were in favour of the statement, "Good visionary school leadership provides visionary product in the shape of students to the nation". Neither participant was neutral nor was against the statement. Mean score 4.66 is significant to prove that the participants have the same opinion about the statement.

The mean of the mean scores is 4.45 which means that the data are statistically significant i.e. the school leadership is responsible to develop academic achievements in students' personalities. 4. APPEARANCE

\begin{tabular}{llllllll}
\hline S. No. & \multicolumn{1}{c}{ Item } & $\begin{array}{c}\text { SA } \\
\%\end{array}$ & $\begin{array}{l}\text { A } \\
\%\end{array}$ & $\begin{array}{l}\text { N } \\
\%\end{array}$ & $\begin{array}{l}\text { D } \\
\%\end{array}$ & $\begin{array}{l}\text { SD } \\
\%\end{array}$ & Mean \\
\hline 1. & Physical & 44.25 & 50.45 & 2.65 & 2.65 & & 4.36 \\
2. & Aesthetic & 45.13 & 54.87 & & & & 4.45 \\
3. & Role Model & 46.90 & 53.10 & & & & 4.47 \\
& Mean of the Means & & & & & $\mathbf{4 . 4 3}$
\end{tabular}

Table 4 reflects the data about 'Appearance'. It is evident from the table that: $94.70 \%$ of participants agreed the statement, "Outlook and style of school leadership is a source of inspiration for the students". $2.65 \%$ of participants were neutral while $2.65 \%$ of participants were against the statement. So, it was proved the statement. Mean score 4.36 is significant to prove that the participants have the same opinion about the statement.

$100 \%$ of participants agreed on the statement, "A healthy school leadership motivates the students towards health-supporting activities". A mean score of 4.45 is significant.

$100 \%$ of participants agreed on the statement, "School leadership is the best role model which could mold students' personality in positive directions". A mean score of 4.47 is significant.

The mean of the mean scores is 4.43 which mean that the data are statistically significant i.e. the school leadership develops physical and aesthetic sense in students' personality.

\section{Conclusion}

1. The majority of the principals and teachers involved in the study agree that the school leadership develops the moral values in the students' personalities.

2. Majority of principals and teachers agree that the school leadership is responsible to develop emotional values in students' personality

3. The majority of the principals and teachers agree that academic achievement, enabling environment, cooperative skill, discipline, punctuality, study habits, leadership, and vision are developed in students' personalities by the school leadership.

4. The majority of the principals and teachers agree that physical appearance and aesthetic sense of school leadership affect the students' personality development.

\section{Recommendations}

The current study was conducted to investigate the impact of school leadership on students' personality development. In the light of findings and conclusions, it is recommended to the higher authorities of the education department and selecting authorities that

- $\quad$ In the recruitment process of the school principal, preference should be given to the candidate who has good personality characters.

When senior teachers are to be promoted as principal, their annual confidential reports should be kept in study. Then in the light of their concerned principals' opinions, they are promoted.

Only seniority list is not sufficient for promotion as principal, seniority-cum-fitness should be the criteria for the school principal.

Workshops and seminars should be conducted on personality development factors to equip

References school leaders with skills and abilities increasing the level of job satisfaction.

Bolam, R.(1999). Educational Administration, Leadership, and Management: towards a research agenda, in Bush, T. (2008). Leadership and Management Development in Education. London: SAGE publications Ltd.

Bush, T. (2008). Leadership and Management Development in Education. London: SAGE Publications Ltd. 
Cohen, L., Manion, L., \& Morrison, K.(2000). Research Methods in Education (Edition, $5^{\text {th }}$ ). London: Routledge Falmer.

English, Fenwick.W.W.(2006). Encyclopedia of Educational Leadership and Administration, Volume 2(L-Z). California: SAGE Publication.

Goleman, D.(1998). Working with Emotional Intelligence. New York: Bantam Books.

Jerome, K. (1971). Personality Development, $2^{\text {nd }}$ edition. New York: Holt Jovaovich, Inc.

Khan N, NM Aajiz, A Ali (2018) Comparison of Management Practices in Public and Private Universities in Khyber Pakhtunkhwa Journal of Education and Educational Development, Volume 5 Issue 1, 2018.

Khan, Muhabat. And Shaheen, Ijaz(2016). The Leadership Role of Secondary School Principals and Its Impact on Students' Academic Achievement. In FWU Journal of Social Sciences, Summer 2016, volume 10, No.1.

Liethwood, K., Seashore Louis, K., Anderson, S., and Wahistrom(2004). How Leadership Influences Students Learning (Review of Research). The Wallace Foundation Centre for Applied Research and Educational Management. Ontario Institute for Studies in Education.

Mulford, B.(2003). School Leaders; Challenges, Role, and Impact on Teacher and School Effectiveness. Tasmania: OECD Commissioned Paper.

Persson, N.B.G. (2004). A Study of Personality and Family and School Environment and possible International Effects in 244 Swedish Children-A Multiple Regression Analysis. Psychology, 5886-895.

Rahman, M.N.(2014). Characteristics and Trends need for Personality Development for Manifold Sphere of Management. International Journal of Scientific Engineering and Research (IJSER), Volume 3, Issue August 8, 2015. 54 of 57.

Rashid, M.(1997). School Guide: Educational Psychology, Code No. 840. Islamabad: Allama Iqbal Open University.

Sapre, P. (2002). 'Realizing the Potential of Educational Management in India' Education Management and Administration, 30(1):101-8.

Sheebha, K.N.(2016). A Study on Relation Between Study Habits and Personality Traits of Higher Secondary Students. In the international Journal of research-Granthaalyah, vol.4, No.5: SE(2016):40-43.

Smith, Stuart, C., Mazzarella, Jo Ann., and Piele, Philip, K.(1981). School Leadership: Handbook for Survival. Washington, D.C.: National Institute of Education (ED).

Wekessa, G.W.(1993). The Impacts Of Head Teachers' Instructional Leadership on Student Academic Achievement in Kenya, Unpublished Ph.D. Dissertation, Teachers College Columbia University. 